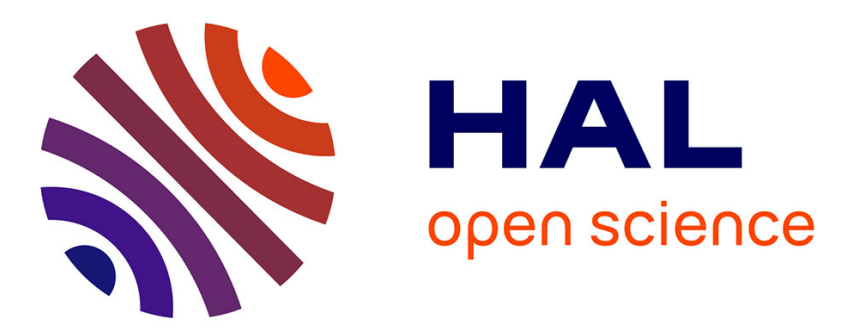

\title{
ACTIVATION OF MUSCARINIC CHOLINERGIC RECEPTORS STIMULATES INOSITOL PHOSPHATES SYNTHESIS IN THE DEVELOPING AVIAN COCHLEAR DUCT
}

Sylvain Bartolami, Ebrahim Mayat, William R Lippe, Guy Rebillard, Remy Pujol

\section{To cite this version:}

Sylvain Bartolami, Ebrahim Mayat, William R Lippe, Guy Rebillard, Remy Pujol. ACTIVATION OF MUSCARINIC CHOLINERGIC RECEPTORS STIMULATES INOSITOL PHOSPHATES SYNTHESIS IN THE DEVELOPING AVIAN COCHLEAR DUCT. International Journal of Developmental Neuroscience, 1992, 10, pp.31 - 36. hal-02163286

\section{HAL Id: hal-02163286 https://hal.science/hal-02163286}

Submitted on 24 Jun 2019

HAL is a multi-disciplinary open access archive for the deposit and dissemination of scientific research documents, whether they are published or not. The documents may come from teaching and research institutions in France or abroad, or from public or private research centers.
L'archive ouverte pluridisciplinaire HAL, est destinée au dépôt et à la diffusion de documents scientifiques de niveau recherche, publiés ou non, émanant des établissements d'enseignement et de recherche français ou étrangers, des laboratoires publics ou privés. 


\title{
ACTIVATION OF MUSCARINIC CHOLINERGIC RECEPTORS STIMULATES INOSITOL PHOSPHATES SYNTHESIS IN THE DEVELOPING AVIAN COCHLEAR DUCT
}

\author{
Sylvain Bartolami, ${ }^{*}$ Ebrahim Mayat, William R. Lippe, $\dagger$ GuY Rebillard and Remy Pujol
}

INSERM-U 254, Laboratoire de Neurobiologie de l'Audition, Hôpital St Charles, 34059 Montpellier Cedex 01, France

(Received 6 February 1991; in revised form 27 September 1991; accepted 30 September 1991)

\begin{abstract}
We previously reported that the inositol phosphates (IPs) synthesis is induced by muscarinic agonists in the rat cochlea and that this stimulation is maximal at postnatal day 12 . This peak response is concomitant with the onset of the efferent synaptogenesis at the outer hair cell level. Whether the correlation between this neuronal plasticity and the enhanced IPs formation is unique to the rat or a general feature of the developing vertebrate cochlea is not known. To examine this question, we measured, in the presence of $\mathrm{LiCl}$, the accumulation of $\left({ }^{3} \mathrm{H}\right)$-IPs induced by carbachol, in the developing chick cochlear duct during a period ranging from embryonic day (E) 8 to post-hatching day (P) 20 . Carbachol $(1 \mathrm{mM})$ causes a significant increase of IPs formation relative to basal values at all ages. This IPs accumulation is maximal at E8 ( $1854 \%$ of the basal level), then, rapidly decreases until P13 when it reaches a steady-state level of $294 \%$ of the basal level. Strikingly, this gradual decline in IPs formation is interrupted between E15 and E19, by a transient increase in IPs synthesis. This rise peaks at E16 with a stimulation value of $757 \%$ of the control level. This maximal stimulation is inhibited by atropine in a dose-dependent manner, as is the case at $\mathrm{E} 9$, suggesting the involvement of muscarinic receptors. Interestingly, the occurrence of the peak response is concomitant with the plastic events associated with the maturation of the efferent innervation of the cochlear duct. Thus, these results suggest that there may be a correlation between cochlear plasticity and enhanced IPs synthesis, which is not species-specific The possible significance of the overall decrease in IPs formation, occurring during embryonic development, is discussed.
\end{abstract}

Key words: cochlear duct, inositol phosphates, muscarinic cholinergic receptors.

The degradation of membrane phosphatidylinositol 4,5 biphosphate, by the enzyme phospholipase $\mathrm{C}$, leads to the formation of diacylglycerol and inositol phosphates (IPs). Among these metabolites, diacylglycerol and inositol 1,4,5-trisphosphate are considered as second messengers. ${ }^{4}$ The former directly activates the protein kinase $C$ enzymes; the latter elicits a massive release of calcium from intracellular stores. This transduction system has been found to be driven by specific agonist-activated receptors such as muscarinic cholinergic receptors. ${ }^{7}$

We previously reported that this transduction system is stimulated, in the rat cochlea, by muscarinic cholinergic agonists probably, via the activation of a $\mathbf{M}_{3}$ muscarinic receptor ${ }^{8}$ During the postnatal development of the mammalian cochlea, the muscarinic agonist-induced IPs formation is characterized by a peak around postnatal day $12 .^{3}$ This peak coincides with a time period during which plastic events lead to the setting up of the mature efferent innervation of the outer hair cells of the organ of Corti. ${ }^{11}$ These efferent terminals are thought to be cholinergic. ${ }^{6}$ Thus, it is conceivable that the IPs metabolism may play a role in cochlear neural plasticity. Whether this concomitance, between the increased IPs synthesis and the efferent synaptogenesis, is an overall developmental process in the vertebrate inner ear or is a specific feature of the rat cochlea remains to be investigated.

To address this question, we studied the pattern of the phosphoinositide breakdown during the development of the chick basiler papilla. Although phylogenetically remote, the avian basilar papilla and the mammalian organ of Corti share some morphological homologies. They both possess, for instance, two types of hair cells lying on a basilar membrane and covered by a tectorial membrane. The sensory hair cells are innervated, in both classes, by four different types of fibres, two of them belonging to the efferent systems and the other two to the efferent systems. ${ }^{11,16,23,25}$ Finally, physiological evidence, supporting the possibility of the presence of muscarinic receptors in the chick auditory organ, as this is the case in the rat cochlea, ${ }^{3,8}$ is

\footnotetext{
*Author to whom correspondence should be addressed.

†Present address: Department of Otolaryngology-Head and Neck Surgery, University of Washington, Seattle WA 98195 , U.S.A.

Abbreviations: IPs, inositol phosphates; E, embryonic day; P, post-hatching day.
} 
provided by Shigemoto and Ohmori. ${ }^{19}$ They showed that the application of muscarinic agonists, to isolated chick hair cells, induce a rise in intracellular calcium. On the other hand, the avian and mammalian cochleas differ widely, both in their overall organizations (being respectively ductal and coiled), and in the course of their anatomo-functional maturations. Indeed, the development of the chick cochlear duct is complete in ovo and adult-like physiological responses can be recorded at birth ${ }^{17}$ whereas the rat cochlea is considered to become mature, in terms of tuning and hearing threshold, during the third postnatal week. ${ }^{12.15}$

Consequently, we chose the chick cochlear duct as an example of an avian auditory organ and a model for this developmental study for the following reasons. (1) The development of the chick basilar papilla is well documented. (2) The chick cochlear duct shares some features with the rat cochlea that allow for their comparison. (3) Since the time course of the auditory organogenesis notably differs in the chick and in the rat, the existence of a cause to effect relationship suggested by a concomitance between a rise in IPs synthesis and a given developmental event (the development of the efferent synaptogenesis, for instance) can be usefully tested by measuring the IPs formation in embryonic and post-hatching cochlear ducts. This measurement was carried out in the absence and in the presence of carbachol, a muscarinic preferring agonist.

\section{EXPERIMENTAL PROCEDURES}

Materials. Myo-[2- $\left.\left({ }^{3} \mathrm{H}\right)\right]$-inositol (specific activity: $17 \mathrm{Ci}$ per mmol) was obtained from CEA Saclay (France). Atropine and carbachol was purchased from Sigma (France). All other compounds were of analytical grade.

Dissection of the cochlear ducts. Fertilized chicken eggs were incubated at $37^{\circ} \mathrm{C}$ in a humid atmosphere to allow the embryos to develop. For the needs of this survey, more than 30 chickens of increasing ages (day of hatching, P2, P6, P13, P18 and P22) and more than 250 chick embryos aged from E8 to E20 were killed by cervical transection. Cochlear ducts, from embryos younger than E8, were not used due to the long time necessary for their dissection and due to the large number of cochlear ducts needed per experiment, thus resulting in a reduced viability of the tissue. Our survey was stopped at P20, an age where the cochlear duct is fully mature. The chick embryos were carefully staged according to the criteria of Hamburger and Hamilton. ${ }^{9}$ Cochlear ducts obtained from each hatchling were staged according to the number of post hatching days. The cochlear ducts were dissected under a stereoscopic dissecting microscope. Intact cochlear ducts were rapidly collected in Krebs-Ringer buffer (concentration in mM: $125 \mathrm{NaCl}, 3.5 \mathrm{KCl}$, $1.25 \mathrm{KH}_{2} \mathrm{PO}_{4}, 1.2 \mathrm{MgSO}_{4}, 1.5 \mathrm{CaCl}_{2}, 25 \mathrm{NaHCO}_{3}$ and 10 glucose). The cochlear ducts were maintained throughout the experiment in this buffer, which was equilibrated to $\mathrm{pH} 7.4$ before use and kept at this $\mathrm{pH}$ during the whole duration of the experiment by saturation with a gaseous mixture of $\mathrm{O}_{2} 95 \%$ and $\mathrm{CO}_{2} 5 \%(\mathrm{vol} / \mathrm{vol})$.

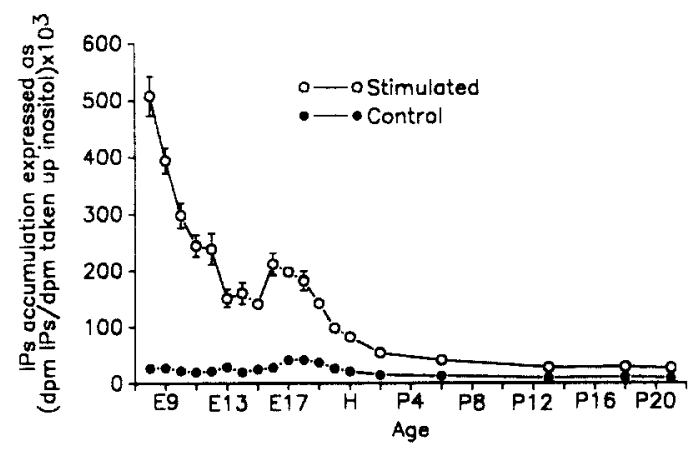

Fig. 1. Developmental changes in basal and carbachol-stimulated levels of IPs synthesis in the cochlear duct of the chick. Following the incorporation of $\left({ }^{3} \mathrm{H}\right)$-myoinositol for 75 minutes at $37^{\circ} \mathrm{C}$, the cochlear ducts were washed and incubated for 15 minutes in $10 \mathrm{mM} \mathrm{LiCl}$ and then for a further 20 minutes in the absence or the presence of $1 \mathrm{mM}$ carbachol. The data are expressed as $\mathrm{dpm}\left({ }^{3} \mathrm{H}\right)-\mathrm{IPs} \times 10^{3} / \mathrm{dpm}$ $\left({ }^{3} \mathrm{H}\right)$-inositol. The IPs accumulation was measured for each cochlear duct and the values presented are the means \pm s.e.m. of 6 to 15 independent experiments. When error bars are not indicated in the figure, the width of the error bars are smaller than the thickness of the symbols. $H$ : hatching. 
Radioactive incorporation. The radioactive inositol incorporation in the cochlear ducts were carried out at $37^{\circ} \mathrm{C}$, for 75 minutes in Krebs-Ringer buffer containing $1 \mathrm{mM}$ cytidine and $50 \mu \mathrm{Ci}$ of myo- $\left[2-\left({ }^{3} \mathrm{H}\right)\right]$-inositol. Labelling of the cochlear ducts, pooled into groups of the same stage of maturation, as carried out by using $67 \mu \mathrm{l}$ of radioactive Krebs-Ringer buffer per cochlear duct. Each group of cochlear ducts was then washed four times using Krebs-Ringer buffer, pH 7.4, at $37^{\circ} \mathrm{C}$. The cochlear ducts were then individually distributed in plastic test tubes containing $500 \mu \mathrm{l}$ of Krebs-Ringer buffer. The tubes were then quickly transferred to a water bath thermostatted at $37^{\circ} \mathrm{C}$ and continuously bubbled with the mixture of $\mathrm{O}_{2} 95 \%$ and $\mathrm{CO}_{2} 5 \%$.

Agonist stimulation and tritiated IPs extraction. $\mathrm{LiCl}(10 \mathrm{mM})$ and atropine (at various concentrations, where applicable) were added to each tube, 15 minutes prior to carbachol stimulation. Carbachol $(1 \mathrm{mM})$ was allowed to react for 20 minutes. The reaction was then stopped by the application of $50 \mu$ l of perchloric acid $(72 \%)$ per tube and by placing the tubes on ice. The cochlear ducts were homogenized by sonication, the homogenates were then centrifuged at $2000 \mathrm{~g}$ for 20 minutes. The resulting supernatants, containing the $\left({ }^{3} \mathrm{H}\right)$-IPs, extracted by the perchloric acid, were taken and neutralized with $1.5 \mathrm{M} \mathrm{KOH} / 0.075 \mathrm{M}$ HEPES. After separation by anionexchange chromatography, the $\left({ }^{3} \mathrm{H}\right)$-IPs formed in the absence or the presence of carbachol were measured in each cochlear duct, as previously described. ${ }^{8}$

Data expression and statistical analysis. The results were expressed as $10^{3} \times$ the ratios of the quantity of dpm corresponding to $\left({ }^{3} \mathrm{H}\right)$-IPs accumulated to the amount of dpm of $\left({ }^{3} \mathrm{H}\right)$-inositol taken up per cochlear duct $\left(\mathrm{dpm}\left({ }^{3} \mathrm{H}\right)\right.$-IPs $\times 10^{3} /\left({ }^{3} \mathrm{H}\right)$-inositol). The statistical comparison of $\left({ }^{3} \mathrm{H}\right)$-IPs formation in control and carbachol-stimulated cochlear ducts was performed using two tailed Student's $t$-test.

\section{RESULTS}

IPs formation during development. The developmental changes of the carbachol-induced phosphoinositide degradation are shown in Fig. 1. For each stage of maturation the values of IPs accumulation were expressed as the means \pm s.e.m. of individual experiments, which varied in number from 6 to 15. Throughout the studied period of development, the incorporation of $\left({ }^{3} \mathrm{H}\right)$-myoinositol was constant and the mean level ( \pm s.d.) of the incorporation was $1133 \pm 392$ $\mathrm{dpm}$ of $\left({ }^{3} \mathrm{H}\right)$-myoinositol taken up/ $\mu \mathrm{g}$ protein. The basal levels of IPs accumulation are small at all ages, being somewhat greater during embryonic development than after hatching, since the mean basal values are respectively $28 \pm 1$ (s.e.m.) and $11 \pm 0 \mathrm{dpm}\left({ }^{3} \mathrm{H}\right)$-IPs $\times 10^{3} / \mathrm{dpm}\left({ }^{3} \mathrm{H}\right)$-inositol during embryonic and post-hatching development. Carbachol causes a significant increase of IPs formation relative to the basal values (Fig. 1$)$ at all ages $(P<0.0001$ in all cases, the $p$ values were obtained by a two-way analysis of variance). The carbachol-elicited IPs accumulation is maximal at E8, with a level equal to $508 \pm 34 \mathrm{dpm}\left({ }^{3} \mathrm{H}\right)$-IPs $\times 10^{3} / \mathrm{dpm}\left({ }^{3} \mathrm{H}\right)$-inositol. Such a level represents $1854 \%$ of its control value. The magnitude of IPs formation then decreases switfly until P13 when it reaches a steady-state level of $294 \%$ of the corresponding non-stimulated value. This otherwise gradual decline in IPs formation is interrupted, between E15 and E19, by a statistically significant increase in the magnitude of the stimulated response. This increases reaches, at the E16, the peak value of $212 \pm 20 \mathrm{dpm}\left({ }^{3} \mathrm{H}\right)$-IPs $\times 10^{3} / \mathrm{dpm}\left({ }^{3} \mathrm{H}\right)$-inositol taken up, that is, $757 \%$ of the control level at this age (Fig. 1). During this period of enhanced carbachol-stimulated IPs synthesis, there is also a relative increase in basal IPs metabolism that is significantly different from the basal responses obtained during earlier embryonic development (that is, from E8 to E14).

Dose-response curves of the carbachol stimulation at E9 and E16. The dose-response curves were drawn from data obtained by stimulating, with carbachol at increasing concentrations $(1 \mu \mathrm{M}$ to $10 \mathrm{mM}$ ), the IPs formation at E9 and E16 (Fig. 2). These ages were taken as samples of the two phases of the pattern of the developmental IPs synthesis (the overall decrease and the transient peak). The data points were expressed as percentages of the level of non-stimulated IPs formation, that is $27 \pm 6 \mathrm{dpm}\left({ }^{3} \mathrm{H}\right)$-IPs $\times 10^{3} / \mathrm{dpm}\left({ }^{3} \mathrm{H}\right)$-inositol at E9 and $28 \pm 7 \mathrm{dpm}\left({ }^{3} \mathrm{H}\right) \mathrm{IPS} \times 10^{3} / \mathrm{dpm}$ $\left({ }^{3} \mathrm{H}\right)$-isositol at E16 (mean \pm sem). From these curves, $\mathrm{EC}_{50}$ values were determined and show that carbachol induces IPs accumulation with a greater potency at E9 than at E16 since the $\mathrm{EC}_{50}$ values are respectively $0.11 \mathrm{mM}$ and $0.43 \mathrm{mM}$. At both ages, the stimulation saturates from concentrations of carbachol greater than or equal to $1 \mathrm{mM}$. However the respective values of these 
plateaus differ notably with age: at E9 the maximal response is about $1431 \%$ of the basal level while it only reached $742 \%$ at E16.

Effects of atropine on the carbachol-evoked IPs formation. Experiments of cholinergic antagonism were undertaken at E9 and E16, by the application of several concentrations of atropine $(1 \mathrm{nM}, 10 \mathrm{nM}$ and $1000 \mathrm{nM})$ prior to carbachol $(1 \mathrm{mM})$ stimulation. These experiments were replicated at least 6 times. At E9, atropine strongly reduces the stimulated IPs accumulation, in a dose-dependent manner (Fig. 3). Smaller effects are caused by atropine at E16. Indeed, atropine shows a weaker dose-dependent inhibition of the stimulated level (Fig. 3), when compared to the effects of atropine at E9 (Fig. 3), since atropine ( $1 \mathrm{nM})$ provokes a $75 \%$ inhibition of the carbachol stimulated response at E9 while it does not significantly alter the stimulated IPs accumulation at E16. However, at both ages, atropine (1000 nM) blocks almost completely the carbachol-evoked IPs formation, the effects of atropine resulting in 95 and $90 \%$ inhibitions at E9 and E16 respectively.

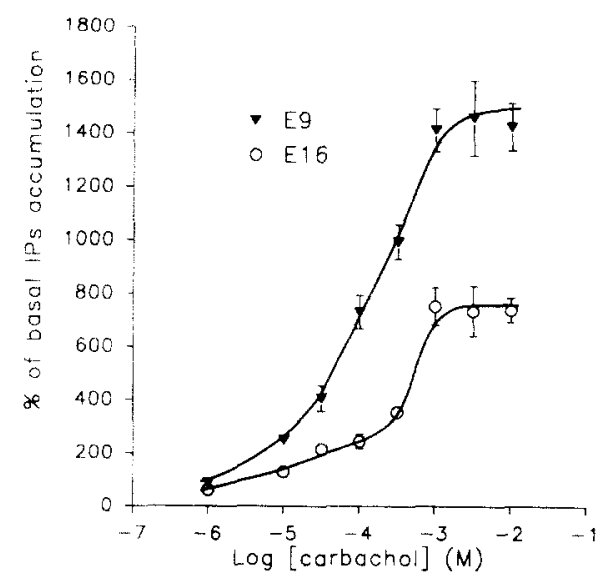

Fig. 2. Dose-response curves of the carbachol-stimulated IPs synthesis at E9 and E16. The IPs formation was measured for each cochlear duct and expressed as percentage of the values of the mean basal IPs accumulation determined at each age. These mean basal levels are $27 \pm 6(\mathrm{sem}) \mathrm{dpm}\left({ }^{3} \mathrm{H}\right)$-IPs $\times 10^{3} / \mathrm{dpm}$ $\left({ }^{3} \mathrm{H}\right)$-inositol and $28 \pm 7 \mathrm{dpm}\left({ }^{3} \mathrm{H}\right)$-IPs $\times 10^{3} / \mathrm{dpm}\left({ }^{3} \mathrm{H}\right)$-inositol at E9 and E16 respectively. The data points are means \pm sem of 6 experiments, at least. When error bars are not indicated on the graph, the width of the error bars are smaller than the thickness of the symbols.

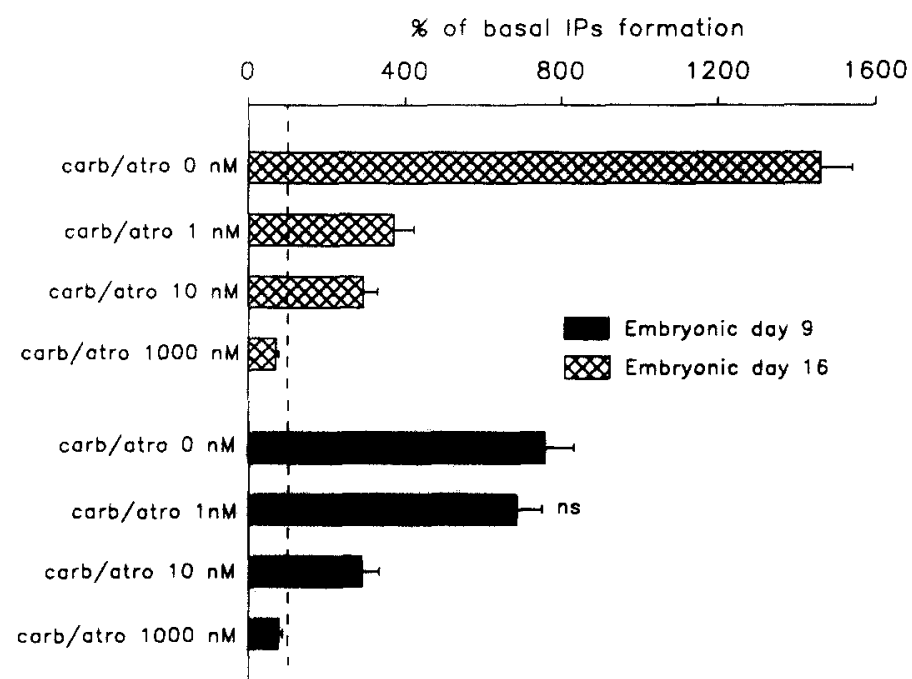

Fig. 3. Effects of atropine on the carbachol-induced IPs formation in the E9 and E16 cochlear ducts. Atropine $(1,10,1000 \mathrm{nM})$ was applied 15 minutes prior to stimulation with carbachol $(1 \mathrm{mM})$. The IPs formation was measured for each cochlear duct and expressed as percentage of the mean basal values of IPs accumulations that are the same as in Fig. 2. The $100 \%$ level is indicated by the dash line. The data points are means \pm sem of at least 6 experiments. Carb.: carbachol, atro.: atropine, ns: the effect is non-significant. 


\section{DISCUSSION}

The present data show that phosphoinositide metabolism is present during the organogenesis of the avian cochlear duct and that this metabolism can be enhanced by a cholinergic muscarinic agonist in a dose-dependent fashion. Moreover, the developmental pattern of the carbacholelicited IPs formation, characterized by two phases: an overall decrease and a transient increase (Fig. 1), suggests the occurrence of two distinct phenomena with respect to phosphoinositide metabolism. During both phases, the increase in IPs accumulation was due to selective interactions of carbachol with muscarinic receptors since the carbachol-enhanced IPs synthesis could be almost completely inhibited by the application of atropine at $1 \mu \mathrm{M}$ (Fig. 3).

Decline in the stimulated IPs formation during the embryonic development. The phenomenon, depicted by a fall in IPs synthesis, may be related to changes in the rate of cell division within the cochlear duct. Indeed, much evidence linking phosphoinositide metabolism with mitosis has been reported in the literature. An activation of the phosphoinositide catabolism that leads to an increase in intracellular free calcium, can trigger entry into mitosis. Together with the cytoplasmic calcium rise, diacylglycerol, the other second messenger of this transduction system, can activate several kinases, ultimately resulting in protein phosphorylation and gene activation. ${ }^{14}$ Recent surveys $^{20,22}$ demonstrated that microinjections of inositol 1,4,5-trisphosphate or calcium induce the onset of mitosis in sea urchin embryonic cells. Similar control of entry into mitosis by inositol 1,4,5-trisphosphate and calcium has also been reported in mammalian and plant cells. ${ }^{24}$ In addition, carbachol strongly stimulates DNA synthesis via the activation of muscarinic receptors in primary astrocytes, brain-derived cell lines and transfected $\mathrm{CHO}$ cells. ${ }^{2}$ Thus, considering that IPs formation may be linked to the triggering of mitosis, it is conceivable that the decrease in IPs formation, reported here, could be related to a reduction in the rate of mitosis in the avian inner ear. In this organ, the sensory hair cells of the basilar papilla stop dividing by E10. ${ }^{21}$ Recent works, ${ }^{10}$ using tritiated thymidine labelling, showed that not only the hair cells but also the supporting cells complete their terminal mitoses during this period. On the other hand, Ard and Morest ${ }^{1}$ showed the occurrence of cell death in both the cochlear and vestibular ganglia of the chick embryo. The course of the cell death event stretches from E8 to E14, a time period that closely coincides with the first, steep part of the decrease in IPs accumulation (Fig. 1). This suggests that the fall in the magnitude of the IPs formation might be partially due to this cell death phenomenon. All the above observations are in agreement with the hypothesis that the reduction in the IPs synthesis, in the developing avian inner ear, may reflect a slackening of the rate of mitosis and/or a naturally occurring cell death. These observations, however, can not exclude the possibility that other developmental events may, also, account for the fall in IPs accumulation.

Transient enhancement of the stimulated IPs formation. The second phase of the carbacholinduced IPs synthesis, during development is an enhancement of the IPs accumulation. This enhancement stretches from E15 to E19 and peaks at E16. A morphological survey, ${ }^{26}$ using Golgi methods, reported that the very beginning of the innervation of the basilar papilla, by the efferent axons, occurs between E11 and E13. Another investigation ${ }^{5}$ using acetylcholinesterase histochemistry, indicated that rare reaction products, that possibly represent efferent terminals, were first detected at E13. Temporally, these results closely precede the onset of the increase of stimulated IPs synthesis. The very first immature efferent contacts are observed at the base of both tall and short hair cells at E14. ${ }^{18}$ Fibres positively stained for acetylcholinesterase become visible throughout the basilar papilla ${ }^{5}$ between E15 and E17, while well characterized efferent synapses are observed by transmission electron microscopy by E15-E17. ${ }^{27}$ The large efferent synapses, which are extended at the base of the short hair cells, mature by E18 to E20. ${ }^{5,18}$ In summary, the period of carbachol-enhanced IPs formation coincides with neuronal plastic events which lead to the maturation of the efferent innervation of the auditory receptors, especially efferent fibres that form synapses with the short hair cells. Such a correlation has been suggested in the rat cochlea, ${ }^{3}$ where an enhanced IPs synthesis coincides with the formation of the medial efferent synapses with the outer hair cells.

The whole body of these observations suggests that the carbachol-induced IPs accumulation may play a role in efferent synaptogenesis. This hypothesis is in accordance with the general proposal that neurotransmitters may affect neuroplasticity. Indeed, several investigations indicate 
that many neurotransmitters, including acetylcholine, modulate neurite outgrowth, plasticity and neuronal survival in a variety of in vivo and in vitro models (reviewed in reference 17).

Acknowledgements-We are grateful to Fabienne Lebrun for excellent technical assistance and to Pierre Sibleyras for printing the figures. This work was supported by grants from MRT, CNAMTS-INSERM, Air Liquide and the Laboratoires IPSEN (Paris).

\section{REFERENCES}

1. Ard M. D. and Morest D. K. (1984) Cell death during development of the cochlear and vestibular ganglia of the chick. Int. J. Devl. Neuroscience 2, 535-547.

2. Ashkenazi A., Ramachandran J. and Capon D. J. (1989) Acetylcholine analogue stimulates DNA synthesis in brainderived cells via specific mucarinic receptor subtypes. Nature 340, 146-150.

3. Bartolami S., Guiramand J., Lenoir M., Pujol R. and Récasens M. (1990) Carbachol-induced inositol phosphate formation during rat cochlear development. Hearing Res. 47, 229-234.

4. Berridge M. J. (1984) Inositol trisphosphate and diacylglycerol as second messengers. Biochem. J. 220, 345-360.

5. Cohen G. M. (1987) Acetylcholinesterase activity in the embryonic chick's inner ear. Hearing Res. 28, 57-63.

6. Eybalin M. and Pujol R. (1987) Choline acetyltransferase (ChAT) immunoelectron microscopy distinguishes at least three types of efferent synapses in the organ of Corti. Exp. Brain Res. 65, 261-270.

7. Fischer S. K. and Agranoff B. W. (1987) Receptor activation and inositol lipid hydrolysis in neural tissues. $J$. Neurochem. 48, 999-1017.

8. Guiramand J., Mayat E., Bartolami S., Lenoir M., Rumigny J. F., Pujol R. and Recasens M. (1990) A M muscarinic $_{3}$ receptor coupled to inositol phosphate formation in the rat cochlea. Biochem. Pharmac. 39, 1913-1919.

9. Hamburger V. and Hamilton H. L. (1951) A series of normal stages in the development of the chick embryo. $J$ Morphol. 88, 49-92.

10. Katayama A. and Corwin J. T. (1989) Cell production in the chicken cochlea. J. Comp. Neurol. 281, 229-235.

11. Lenoir M., Shnerson A. and Pujol R. (1980) Cochlear receptor development in the rat with emphasis on synaptogenesis. Anat. Embryol. 160, 253-262.

12. Lenoir M. and Puel J. L. (1987) Development of $2 \mathrm{f}_{1}-\mathrm{f}_{2}$ otoacoustic emissions in the rat. Hearing Res. 29, $265-271$.

13. Lipton S. A. and Kater S. B. (1989) Neurotransmitter regulation of neuronal outgrowth, plasticity and survival. Trends Neurosci. 12, 265-270.

14. Pardee A. B. (1989) $G_{1}$ events and regulation of cell proliferation. Science 246, 603-608.

15. Puel J. L. and Uziel A. (1987) Correlative development of cochlear action potential sensitivity, latency, and frequency selectivity. Devl. Brain Res. 37, 179-188.

16. Pujol R., Carlier E. and Devigne C. (1978) Different patterns of cochlear innervation during the development of the kitten. J. Comp. Neurol. 177, 529-536.

17. Rebillard G. and Rubel E. W. (1981) Electrophysiological study of the maturation of auditory responses for the inner ear of the chick. Brain Res. 229, 15-23.

18. Rebillard M. and Pujol R. (1983) Innervation of the chicken basilar papilla during its development. Acta otolaryngol. 96, 379-388.

19. Shigemoto $T$. and Ohmori H. (1990) Muscarinic agonists and ATP increase in intraceliular Ca concentration in the chick cochlear hair cells. J. Physiol., London 420, 127-148.

20. Steinhardt R. A. and Alderton J. (1988) Intracellular free calcium rise triggers nuclear envelope breakdown in the sea urchin embryo. Nature 332, 364-366.

21. Tilney L. G., Tilney M. S., Saunders J. S. and DeRosier D. J. (1986) Actin filaments, stereocilia, and hair cells of the bird cochlea. III. The development and differentiation of hair cells and stereocilia. Devl. Biol. 116, 100-118.

22. Twigg, J., Patel R. and Whitaker M. J. (1988) Translational control of InsP $\mathrm{P}_{3}$-induced chromatin condensation during early cell cycle of sea urchin embryos. Nature 332, 366-369.

23. Warr W. B. and Guinan J. J. (1979) Efferent innervation of the organ of Corti: Two separate systems. Brain Res. 173, $152-155$.

24. Whitaker M. J. and Patel R. (1990) Calcium and cell cycle control. Development 108, 525-542.

25. Whitehead M. C. and Morest D. K. (1981) Dual populations of efferent and afferent cochlear axons in the chicken. Neuroscience 11, 2351-2365.

26. Whitehead M. C. and Morest D. K. (1985a) The development of innervation patterns in the avian cochlea. Neuro science 14, 255-276.

27. Whitehead M. C. and Morest D. K. (1985b) The growth of cochlear fibers and the formation of their synaptic endings in the avian inner ear: a study with the electron microscope. Neuroscience 14, 277-300. 